reductions in some copyright permissions revenues. However, the APSA Publications Committee, and the Council, have both emphasized that the long-term importance of this project outweigh those risks. Planning for future phases of the project will be undertaken with a careful eye both to maximizing opportunities and protecting the Association's core resources.

College and university libraries interested in subscribing to the electronic JSTOR database can contact Kevin Guthrie at JSTOR, 140 East 62nd Street, New York, New York 10021; Phone: (212) 838-8400.

\section{NSF Sponsorship of National Election Studies Featured on Capitol Hill}

APSA and the University of Michigan joined to sponsor an exhibit on The National Election Studies: A National Resource in the Social Sciences at the second annual exhibition of the Coalition for National Science Funding on Capitol Hill, March 19, 1996. The exhibition featured research sponsored by the National Science Foundation, and was attended by over a dozen members of Congress and hundreds of Hill staff members.

Steven J. Rosenstone, Center for Political Studies, University of Michigan, one of the principal investigators on the National Election Studies (NES) project, and Paul Freedman of the NES staff were on-hand at the exhibition to present materials and answer questions. NSF Director Neal Lane and Deputy Director Anne Petersen also attended. Social and behavioral sciences were well represented at the exhibition, including presentations on the General Social Survey and the Panel Study on Income Dynamics as well as the NES. Overall, close to 80 scientific societies, professional associations, universities, and industrial representatives made presentations. This was the first time that APSA had participated.

The APSA-Michigan exhibit highlighted some key findings from the NES, emphasizing the scientific value of having consistent data

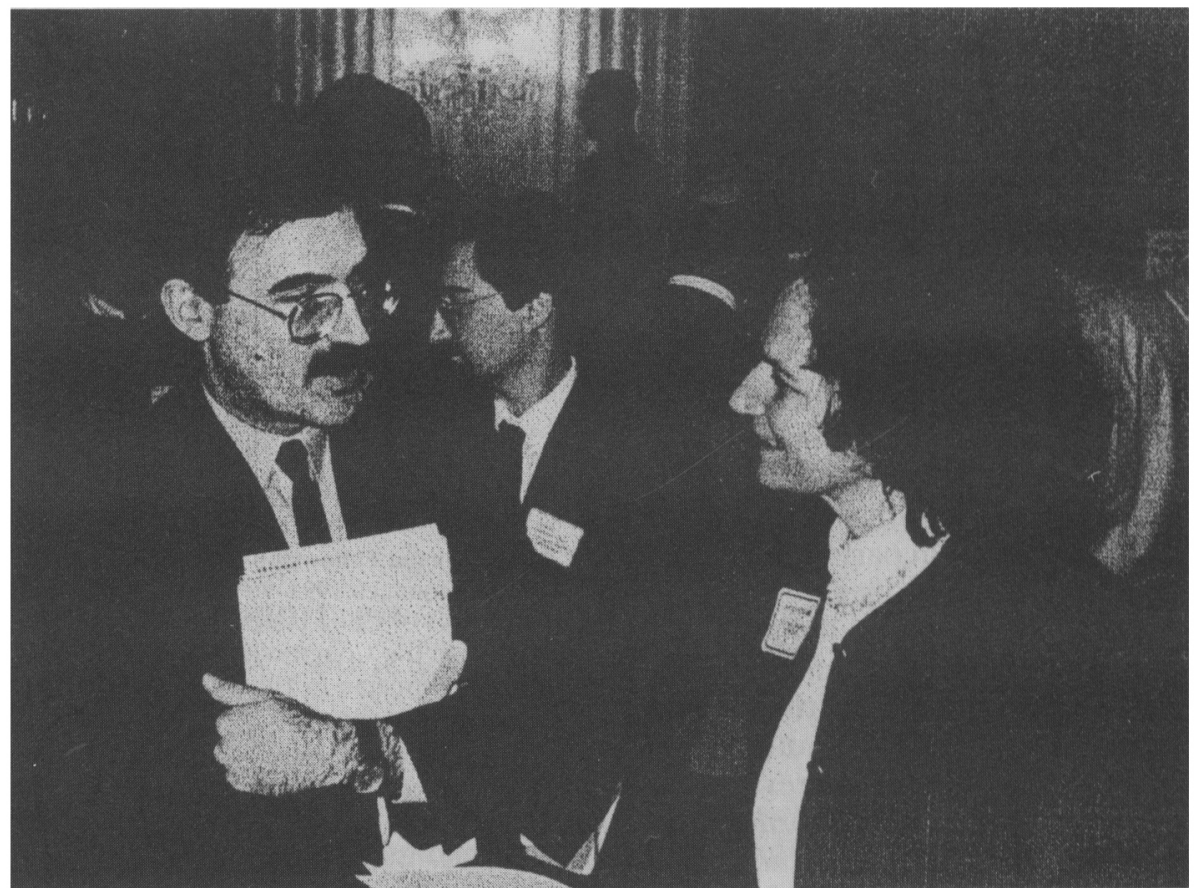

Steven J. Rosenstone, Center for Political Studies, University of Michigan. talks with NSF Deputy Director Anne Petersen at the Coalition of National Science Funding exhibition showcasing research and education projects supported by NSF.

maintained over time and the practical utility of the information. Graphic displays illustrated declining trends in trust in government and shifts in partisan identification. Access to the NES World Wide Web site was also available for demonstrations. (The Web address is http://www. umich.edu/ nes.)

APSA along with the NES principal investigators, other NSF grant recipients, and the social science community has been working actively to advance public awareness of social science research and the importance of sustained NSF support for social, behavioral, and economic sciences. Much of the work has been led by the Consortium of Social Science Associations (COSSA) of which APSA is an active member. COSSA has testified frequently on behalf of social science support on Capitol Hill, and sponsored breakfast round tables on social science applications to public policy. APSA also has been meeting regularly with staff at the White Office of Science and Technology Policy, and with senior staff at the NSF on issues of social science funding and application.

Support for overall funding and for social and behavioral sciences at the NSF in the current budget cutting climate has generally been positive. The FY 1996 NSF appropriation finally achieved approval in April of 1996 in which NSF received a final budget of $\$ 3.22$ billion for FY 1996, compared to $\$ 3.27$ billion for the previous year. The President has requested $\$ 3.3$ billion for NSF for FY 1997. While it is difficult to nail down exact levels of proposed funding by Division at this time, the Division of Social, Behavioral, and Economic Research (SBER) at NSF currently has a proposed funding level for FY 1997 of about $\$ 93$ million, a 9\% increase over FY 1996. House Science Committee authorization report language, though not the bill itself, includes language directing $\mathrm{NSF}$ to reduce the number of directorates by one, and names the Social, Behavioral and Economic Sciences Directorate as the one to be considered for elimination. Representative Walker, who chairs the House Science Committee, has stated, however, that the objective is to help NSF reduce overhead costs overall to free more funds for science, not to target SBE research in particular. There is not thought to be general support in Congress for eliminating SBE research or the SBE directorate, and any differen- 
tial targeting is not expected to emerge in final NSF legislation.

\section{Rick K. Wilson to Join NSF as Political Science Rotator}

Rick K. Wilson is joining the political science program in the Division of Social, Behavioral, and Economic Research at the National Science Foundation on an annual assignment on leave from Rice University. Wilson, professor in the political science department at Rice, and formerly its chair, is a specialist in legislative politics, research methods, social choice and game theory, and normative democratic theory. He is the author, with Cal Jillson, of Congressional Dynamics: Structure, Coordination and Choice in the First American Congress, 1774-1789 (Stanford University Press, 1994.)

The political science program at NSF supports social scientific research to improve the understanding of politics, political behavior, and political institutions and processes. Recent research sponsored by the program includes studies of activists in American political parties, information and issues in voting, support for political institutions, and the process of democratization. Rotators, in collaboration with the program director, Frank Scioli, support the proposal review process and help disseminate information to prospective principal investigators about NSF-funded research opportunities. The rotator position was last filled by John McIver, on leave from the University of Colorado at Boulder.

\section{Index of APSA Reports in PS, September 1995-June 1996}

Article

American Political Science Review

APSR's Book Review, 1991-95

Report of the Managing Editor of the American Political Science Review, 1994-95

Annual Meeting 1995

The Windy City Favors the 1995 Annual Meeting

Large Audiences Drawn to 1995 Panels

Awards

APSA Awards Presented at 1995 Annual Meeting

Committees

Report on the Status of Lesbian and Gays in the Political Science Profession

APSA Committees

Congressional Fellowship Program

CFP Announces 1995-96 Competition Winners

43rd Class of Congressional Fellows Begins 1995-96 Program

Report on the Congressional Fellowship Program

Norman Ornstein to Head CFP Advisory Committee

Council

APSA Council Minutes

APSA Council Minutes, August 1995

Dissertations

Doctoral Dissertations in Political Science, 1994

Executive Director

Report of the Executive Director

Gopher/Internet Report

APSA Gopher Report

APSA Internet Report

Governing Rules

APSA Constitution and Bylaws

Annual Meeting Business Rules

Organized Sections

Section News

Update on Organized Sections

Section News

Section News

Presidents and Officers

Arend Lijphart: A Profile

Treasurer's Report

Kent Jennings Nominated President-Elect

Profession

Ranking Research Doctorate Programs in Political Science

Two-Year College Political Science Faculty: Recruitment and Responsibilities

Job Prospects for Political Scientists: Placement Experience in 1995

Professional Development

Annual Meeting Short Courses Provide Diverse Professional Development Opportunities

1996 Annual Meeting Short Courses

\section{PS Reports}

Index of APSA Reports in PS

Index of Authored Articles

Publications

Publications List

Publications List

Publications List

Publications List

National, Regional, and State Association News

Listing of Regional and State Political Science Associations

Research Support

1995 Research Support Grants Announced

Women and Minorities

1995 Ralph Bunche Summer Institute

Participation by Women in the 1995 Annual Meeting

1996 APSA Minority Fellows

UVA and Paley Foundation Support Bunche Summer Institute
Issue

Page

September 1995

December 1995

December 1995

December 1995

December 1995

September 1995

March 1996

September 1995

December 1995

March 1996

June 1996

September 1995

December 1995

December 1995

September 1995

December 1995

March 1996

June 1996

June 1996

December 1995 December 1995

March 1996

June 1996

December 1995

December 1995

June 1996

December 1995

March 1996

June 1996

December 1995

June 1996

September 1995

September 1995

December 1995

June 1996

March 1996

0

